DOI: https://doi.org/10.24113/ijellh.v8i1.10355

\title{
Orthodox Belief and Social Stigma in Sudha Murthy's Novel
}

\author{
Mahashweta
}

Shakun Joshi

Ph.D. Research Scholar

Department of English

Mody University

Laxmangarh, Rajasthan, India

shakunvjoshi@gmail.com

Dr. A.S. Rao

Associate Professor of English

Head Department of Arts

Mody University

Laxmangarh, Rajasthan, India

1. Introduction

Among the various prolific writers of English in India is a name that does not need an introduction per se. Sudha Murthy is an immensely accomplished business woman, teacher, social worker and an author to reckon with.

Feminism plays an essential role in women rights and Sudha Murthy's novels are rich in dealing with it. This paper is an attempt to analysis Sudha Murthy's novel Mahashweta, a 


\section{DOI: $\underline{\text { https://doi.org/10.24113/ijellh.v8i1.10355 }}$}

powerful text that tells the story of the female protagonist Anupama, who suffered from leucoderma after her marriage and how the social stigma marred her beautiful and confident personality temporarily not permanently because Sudha Murthy's female characters suffer ,struggle under pressure to come out as polished diamonds. They survive the atrocities practiced against them.

\subsection{Orthodox Belief, Feminism And Social Stigma Of Leucoderma}

'Mahashweta', published in the year 2007 deals with a very strong titular character. The novel begins on a note that resonates so strikingly with the feminist sentiment. On the very first page, the male protagonist Anand is introduced. He is a doctor and is involved in the delivery of a girl child in the opening pages of the story. When the child is born, the seasoned and elderly nurse at the hospital delivery room has thoughts that stand true universally, more so in the Indian context:

For a moment Prabhavathi was lost in thought. Even though the female child is stronger than the male child at birth, as adults it is the man who becomes the oppressor, and the woman who suffers. (Chapter 1)

On one hand we get to see the perspective of a female in the above lines on the other even the male counterpart Anand, in this scene, acknowledges the strength of women in certain parts of life. He is discovered thinking about the strength of character of a woman who gives birth to a child despite the obvious pain and troubles:

Both parents play equally significant roles in the birth of a child. But at the moment of birth- the moment of truth- the only reality is the mother.

Sudha Murthy has been able to bring out this gender distinction very vividly in all her works. Mahashweta is a testament of her understanding of the middle class Indian society. 


\section{DOI: $\underline{\text { https://doi.org/10.24113/ijellh.v8i1.10355 }}$}

She herself says that the novel could be placed anywhere in India but she chose the Karnataka backdrop because she herself grew up in that and is deeply familiar with its nuances.

The female protagonist 'Anupama', is a uniquely talented character.

Her resilience and strength shines through all that she does. Mahashweta, another name for goddess Saraswati, is also significant for Anupama because she is wise and talented. Anupama is immensely beautiful and an exceptional actress. Her beauty ensnares Anand and results in their marriage in the novel.

Her only flaw in the marriage market is a poor background. Her qualities far outnumber the flaw that she might possess. She is well- educated and independent, which is how she catches the eye of Dr. Anand, an up and coming doctor. He is mesmerized by her beauty and talent on stage.

Anupama is the daughter of Shamanna, a school teacher and her mother had passed away at a young age, when she was just a baby. Shamanna remarried. His wife Sabakka bore him two daughters. There is obvious bad blood between Anupama and her stepmother:

His wife Sabakka, Anupama's stepmother had told her husband categorically, "Let us not educate her further. It might become difficult to find a husband for her. Besides, she will not support us. She has to marry and go to somebody else's house one day. (Stereotypes and obvious ill feeling between a step mother and daughter.) (Chapter 2)

Anupama's beauty and qualities are in sharp contrast to the plain features and rawness of her step sisters. Anupama's initial decision of not getting married also earns the ire of her step mother:

Sabakka's anger knew no bounds, "This Apsara won't get married herself and insists on destroying my girls' lives!" (Chapter 2) 


\section{DOI: $\underline{\text { https://doi.org/10.24113/ijellh.v8i1.10355 }}$}

When Dr. Anand, who has amassed quite a wealth, is entranced by Anupama and wants to marry her, Sabakka is not too happy. She tells Shamanna that a daughter should be married off amongst equals. Dr. Anand's mother, Radhakka, is a tough nut to crack. She always wanted a match among equals but when she realises that Anand is enamoured and that Anupama is pretty to look at, she decides to neglect her economic background:

What she cannot compromise on, is her standing in the society, so she decides to shoulder or all expenses of the wedding. For Shamanna, this is a match made in heaven.

Two months into the marriage Anand had to leave for England for further training. He wanted to take Anupama along but Radhakka's prime motive for getting Anand married was that her daughter-in-law would be able to sit in for the Lakshmi puja, which she herself could no longer perform as she was widowed(social stigma and orthodox belief regarding being a widow).

Anand goes away and Anupama is left with Radhakka and Girija, her sister-in-law. Radhakka doesn't bother her much until she does as she is asked and behaves as she is expected to as her bahu. But the most unnerving part of her staying with her in laws was her dissociation with the world of art which was her very life blood.

Radhakka will never allow her daughter-in-law to act. Imagine girls from decent families going on stage! Things cannot go on as they did before the marriage. Radhakka will have a heart attack if her daughter-in-law carries on like that.(conservative opinion for working women" (Chapter 2)

Girija is another difficult person to deal with. She is envious of Anupama due to her beauty and looks down upon her due to her background. Anupama accidentally finds out about the promiscuous character of Girija but she could not confront her owing to her own newness in the family and Radhakka's blind love for Girija. 


\section{DOI: $\underline{\text { https://doi.org/10.24113/ijellh.v8i1.10355 }}$}

On the day of the Pujan, a chunk of burning coal falls on Anupama's foot but she does not let it be known. After a few days, the wound heals but is replaced by a white spot. Anupama is perturbed by its appearance. She fears that it might be leukoderma. Women who had this affliction were not looked upon favourably by the society. People often mistook leukoderma for leprosy and hence the apprehension. Anupama had to keep her condition under wraps and somehow find a way of leaving the house unaccompanied in order to see a dermatologist:

Anupama had seen many people with leukoderma but had hardly given them a fleeting thought. However, things were different now. She asked God what sin she had committed to be punished so. (Stigma attached with leukoderma, Chapter 2)

It was a sorry state where a woman like Anupama, who was accomplished in every sense of the word, had to keep a medical condition hidden from others. This says a lot about the position of women in our society. He confirms her worst fears and tells her that although the live coal that fell on her foot didn't do it but she did suffer from leukoderma:

The doctor was aware that tiny white patches like that had ruined many marriages, shattered many hearts, broken many engagements. Most patients who learnt that they had leukoderma were overwhelmed by the social implications of their affliction. (Chapter 3)

When Radhakka finds out, the reaction went beyond the expectation of Anupama. Radhakka is appalled to see the white spot and despite Anupama's entreaties that she had developed this condition after Laxmi Pujan, Radhakka claims that Anupama might have had the affliction even before marriage and that she tricked Anand into marrying her by hiding her condition. 


\section{DOI: $\underline{\text { https://doi.org/10.24113/ijellh.v8i1.10355 }}$}

Whatever she said, Anupama could not stop them from projecting her as the vamp, the deceiver. Her last hope was Anand. She was also confident that Anand being a doctor would side with science and put his mother and sister in the right place by letting them know that leukoderma was nothing to be feared of:

Anupama was ostracized in the house. She could not have her meals with the family. No one bothered to talk to her. She was confined to her room. (social stigma attached with leukoderma)

Meanwhile Radhakka called upon Anupama's poor father Shamanna and blamed him for cheating them all. She said that she could accept them being poor for her son's happiness but hiding this affliction was a deliberate act of deceit and both father and daughter were a part of it.(Orthodox view of blaming girls' parent for all wrong)

Anupama wrote repeatedly to Anand but failed to elicit a response from him. For three years, she lived in her village with her father and step family. The only thing that did happen was that her step-sister Nanda's engagement broke off as word about Anupama's affliction spread. Anupama couldn't attend her dearest friend Sumithra's wedding as her presence on auspicious occasions was not acceptable in society had dawned on Anupama.

Anupama had found out that Anand had come back to India for his sister's wedding. He had not tried getting in touch with her. She had also found out that Radhakka was on the lookout for a match for Anand too. This final piece of information broke her heart. She contemplated suicide:

She had finally discovered the real Anand. He had loved her beauty and married her for it. He was not ready to accept her if her beauty was in any way marred. She recalled a line from one of her plays, 'Why did God give strong arms and the courage of a lion to man?' 'So that he can rescue helpless 


\section{DOI: $\underline{\text { https://doi.org/10.24113/ijellh.v8i1.10355 }}$}

women, the distressed, and the forsaken,' was the reply. But Anand had failed to rise to the occasion and come to her aid. (Chapter 5)

She was seized with misfortune on all sides, she was being ostracized in her village, people had got to know that she had been abandoned by her husband, all this weighed on her more and more and she decided to end her own life. But something rooted deep inside her stopped her from this moment of weakness. She got courage from the realization that none of it was her fault. She had lived an exemplary life till then and could continue to do so. With her new found confidence in herself, she gave up the cowardly thought of ending her own life:

Anupama climbed down the steps. Whatever the circumstances she found herself in, she would meet the challenge head-on, and win. She was now ready to face the world, determined to stand on her own feet and build a new life for herself. (Chapter 5)

She made up her mind to accept Sumi's invitation and go to Mumbai to try her luck and turn a fresh leaf in the monotony and sadness that her life had become.

She was received warmly by Sumithra. She stayed on in their one bedroom apartment and requested Sumi and Hari to get her a job.

In a month or so, Hari procured for her a job as an office assistant and for the first time in years, she had a sense of self. She started regaining her confidence too:

With financial independence, Anupama's confidence began to blossom. (Chapter 6)

Things were looking up for Anupama, she had started forming her own relationships of friendship and trust. Sumi and Hari had been good to her. But, as it inevitably happened in Anupama's life, as it does in the life of many single women throughout the country, normalcy 


\section{DOI: $\underline{\text { https://doi.org/10.24113/ijellh.v8i1.10355 }}$}

was too good to last. Once when she came back from work and Sumithra was still at office, Hari tried to take advantage of her. She was appalled when he said that they could carry out an affair right under Sumithra's nose, without her being any the wiser. Anupama was repulsed. She did not feel it fine to burden Sumithra with the knowledge of her husband's evil designs, so she decided to move out of their apartment under the pretense of having used their hospitality and kindness for far too long. She requested Dolly to arrange for an accommodation for her. Dolly offered her a room in the bungalow which had been passed on to her mother from family as an inheritance.

Once there, she could finally lead her life on her own terms. She got wind of a post of a Sanskrit lecturer in a college lying vacant and she happily took that up, as that was a job she loved:

Anu was sad for a while after she left her old job and joined the college. She missed her colleagues, but as a lecturer she soon became confident and selfassured. She had removed her mangalsutra- it had weighed down on her heavily, in more ways than one. (Chapter 6)

The Sanskrit classics and enacting them on stage had been her life before marriage. And now she got to teach them to the younger lot and direct the plays. She had started earning well and had been supporting her father too by sending him a steady amount every month.

This period in her life, when she becomes completely independent and confident, shows the true strength of her character. She is respected by her students and peers. She looks after her family and is close to her friends. All of this, she achieves despite suffering from leukoderma. Dolly gets married and moves to Australia with her husband but her mother and she decide to leave the bungalow with Anupama for as long as she wanted to stay there 


\section{DOI: $\underline{\text { https://doi.org/10.24113/ijellh.v8i1.10355 }}$}

without rent. Around this time, Anupama is in an accident and fractures and hurts her leg. When she is taken to the hospital, she is unconscious. At the hospital, she is tended to by Dr. Vasant. He finds out that she is a fellow Kannadaga when he and the police constable open her purse to ascertain her identity and he finds a book of kannada plays in Sanskrit there. He is a voracious reader and lover of arts. He takes to the beautiful Anupama and soon they become friends. Vasant and Satya are room- mates and fellow doctors. While Vasant wants to set up a clinic at his village and help out the poor and needy, Satya is more flamboyant and wants to earn the big bucks by setting up practice in the lucrative part of the town.

Both of these young doctors take an instant liking to Anupama. Vasant and Anupama share a common interest in reading and arts, so they have loads to talk about. Once when Satya falls ill, Anupama cares for him, keeps him at her own house and cooks for him on Vasant's request:

During his stay there, Satya had been observing Anupama. He had always thought of her as a beautiful but unfortunate woman; and he had pitied her. But now he felt differently. He saw that she was invariably cheerful, and always ready to help; she did not seem the least bit bothered about the white patches on her body that spoiled her beauty. (chapter 7)

She is still an enigma for the two friends. What they see is a highly confident, respected, down to earth college lecturer, who is revered and adored by her students, what they want to get at is what made her the woman she was. In a world that wasn't easy on single or abandoned women, her reluctance to conveniently label her relationships also amazes them:

'Satya, I have helped you the way any human being would help another; nothing more and nothing less. I don't like being caught in relationships of 
convenience. I don't want to be anyone's 'sister' or 'aunt'. When two men can be friends and two women can be friends, surely a man and a woman can also be just friends.' Satya was taken aback by her blunt answer. It was very uncharacteristic of her. (Chapter 7)

Anupama the bold and beautiful female character of the novel reveals her life's story to Satya during his stay with her for his recuperation. She tells him that her experiences in life made her grow. She wasn't always the confident woman that she came across as. She shares that her philosophy of life did not come from books or education. Her experiences and what she learnt from them made her the woman she was:

'My experiences have taught me this. I have come to realize that courage and confidence are the real wealth in life. Education can improve your chances of success, but ultimately you have to face life all alone. I don't depend on any guru nor do I read any philosophy. My conscience is my guru and it guides me well.' (Chapter 7)

Where on one hand, the author has given us a strong, resilient and meaningful female protaganist, she has also drawn a complex yet naïve male character in the form of Anand. Starting out as a promising and upcoming doctor, dedicated to his work, well-groomed, cultured, polite and decent, Anand later turns out to be a weakling who lacks compassion and courage. This highly trained doctor turned out to be a shallow human being for whom beauty was just skin deep. He was repulsed by her disease and angered at fate for giving him those cards. He did not even deem it fit to reply to any of Anupama's letters. He was the only one who knew that Anupama did not have this affliction before marriage but he did not come to her rescue and let Radhakka treat her like dirt. He abandoned her when he should have stood by her. It is clear that he was a regular male who was just taken in by the beauty of the face. 
He had loved her independent spirit only until he could get her to marry him. Deep down he too was a conservative man who did not have the courage or depth to foray beyond the looks of a woman:

Anand had always had a weakness for beauty. It inspired him to always choose the best of everything. The financial status of his family had only served to encourage his predilection.

Anand had felt then that he was the luckiest man on earth. Anupama was not just his wife, she was the index of his pride. When Anand had first found out that she had leukoderma, he was filled with revulsion. He did not wish to imagine how she would look. (Chapter 8)

In a way, he was far worse than even Radhakka, who at least did not hide behind false liberalism. She was what she was, no pretences. Anand, on the other hand, could have been the anchor that Anupama sought and expected instead he turned out to be a pathetic excuse for a human being who did not possess even a shard of compassion or decency. In his quest for perfection and beauty, he failed to see the gem that Anupama was. He convinced himself that he was doing nothing wrong in abandoning her to her plight. He rationalized his decision of not coming to her rescue, for not honoring his marital vows and for not being the better half that a woman expects.

The novel here deals with the concept of feminism as discussed by Elizabeth Jackson in the book "Feminism and Contemporary Indian Women's Writing" were it is mentioned that some feminist wish to talk about it in terms of difference rather than equality, and some wish to challenge masculine values themselves rather than grant women equal rights within a male-oriented culture. Elizabeth's own understanding of feminism is based not so much on what it is an on what it does: it seeks to analyse and redress the power imbalance between the www.ijellh.com 


\section{DOI: $\underline{\text { https://doi.org/10.24113/ijellh.v8i1.10355 }}$}

sexes, it takes on different forms in different contexts, based as it is on various critical analyses of male privilege and women's subordination within different societies. A replica of the above notion can slightly be felt in Anupama's case wherein the society looks down upon her as a victim of leucoderma and points fingers towards her and not her educated husband who is the real culprit in not accepting Anupama with her flaw despite knowing that leucoderma is harmless.

Doctors like Anand put science and education to shame. It was very late in the story when he realized his mistake. True, he had not remarried even after the constant pressure that Radhakka maintained on him but he had not even tried to contact Anupama in all the years that had gone by. He had no idea how she was faring or whether she was alive or dead. Two years after coming to India, he came across letters for Girija, his sister, from a boy called Vijay. These letters clearly showed their illicit relationship before Girija's marriage. When he confronted his mother with these facts, he was shocked to find out that not only did Radhakka known about it all, she and Girija had covered it all up too. He realized that Anupama knew about it too and yet she hadn't spoken or done any ill to either Girija or his family even when she was ill treated and had reasons to retaliate.

After this realization hit home, Anand tried looking for Anupama and her family. He found out that his father had been transferred to another village and when he reached it he found that Shamanna was long dead. He could not find the whereabouts of his wife or daughters. He realized that he had missed his chance of reconciliation with Anupama. He was rich, successful and a name to reckon with in the society but he was very far away from being a content and happy man. His life could have turned out differently if he had been man enough to support his wife. 


\section{DOI: $\underline{\text { https://doi.org/10.24113/ijellh.v8i1.10355 }}$}

As the years went by, Anupama's popularity in the art circles grew. She directed award winning Sanskrit plays. Her plays won accolades and her students became stars. She was doing what she loved, she had constant friends and a peer group that looked upto her. With Vasant's help, she had put up a play for an international conference of doctors held at Mumbai. After years of knowing her, Vasant had proposed marriage and given her time to mull it over. Meanwhile, unbeknown to any of them, Anand had come to attend that conference and happened to see Anupama at the end of the play, taking a well-deserved applause as a celebrated director. Anand could not believe his luck. For all he knew, Anupama had been lost to him forever and yet she was here now and he could apologise and try to make things right for him and her:

In a daze, Anand watched Anupama walk onto the stage as she had many years ago. Then she had been the heroine of Mahashweta. This time, she was on stage as a real 'Mahashweta'. Her face shone with the same confidence, the same dignity and the same love for theatre. (Chapter 8)

He found out her address and reached her place. Anupama was shocked to see him after all those years and yet she received him with dignity. He tried apologizing but Anupama wasn't in a relenting mood:

'Please sit down. Which mistake are you seeking forgiveness for? Please remember that saying the right thing at the right time is what makes a conversation meaningful. Language is a tool we use to express ourselves. It is what differentiates us from animals. Did you speak when you first got to know about my condition? Was it my fault that I got this white patch? Is it my fault that I am a poor man's daughter? Now that you are here, answer me.' Anand did not know what to say. (chapter 8) 


\section{DOI: $\underline{\text { https://doi.org/10.24113/ijellh.v8i1.10355 }}$}

He told her that he hadn't remarried and that he was finally there to honor all his marital vows that he had failed to do years back. He asked her to consider moving back with him. All the hurt and dark days that Anupama had endured, bubbled back up in her answer:

How can you possibly expect a burnt seed to grow into a tree? Husband, children, affection, love. . they are all irrelevant to me now. It is too late for us. I am no longer the naive Anupama whose world revolved around you. I know what my goals are and where I am heading, and I don't need anyone's help to reach my destination.

With this she sends him back, refusing to be his wife anymore. This shows the resilience of her character. The India that she (and all of us) lives in is a country that still believes in the old adage of patriarchy. 'A woman without her man is nothing' is only now gradually changing to 'A woman, without her man is nothing.'

Anupama knew what she wanted out of her life. Her sense of feminism wasn't marred by over- confidence or pride in her abilities. It was what life had taught her.

It wasn't that she refused Anand because she had a more sensible and reliable option in Dr. Vasant, she had refused to marry him too. She put him down politely, told him to marry someone who could help him in his mission to provide health services to the poor people of the villages. She told him that he would always have a friend in her. She knew that the acceptability of someone like her in a family like Vasant's would again be debatable. She had no doubt as to Vasant's dedication or love towards her but she had seen life too closely in all its ugliness and did not wish to succumb to that kind of treatment again.

When asked about beauty, Vasant had described it in words that had captured her own imagination too: 


\section{DOI: $\underline{\text { https://doi.org/10.24113/ijellh.v8i1.10355 }}$}

One's beauty is seen in one's nature. A good human being who is compassionate to others, who tries to understand the other person's difficulties and reach out to them in their hour of need has real beauty. Such people should always be cherished and honoured. (Chapter 8; vasant's thoughts on beauty)

He was a profound man who could be trusted and therein lay the difference between Anand and Vasant.

But at the end of it all, our Mahashweta chose herself. She chose to be the person she had become. She had once been the moony eyed teen and adult who had believed in love and its power. She believed that love did overcome anything that life might spring up. She had faith in commitment and sacrifice:

"Like Rohini to Chandra, like Lakshmi to Narayana, am I to him?"

Just as the creeper depends on a tree, emotionally I depend on him. I cannot live without him and for his sake, I am ready to renounce everything. Let society say anything it wishes, I do not care. (said by Mahashweta in the play Kadambari repeated in the novel for its main cast) (Chapter 1)

\section{Conclusion}

By the end Anupama turns out to be true MAHASHWETA. She is empowered and believes in herself. She isn't a cynic who would turn away from the concept of love and sacrifice after what she had to go through in her life. Yet she finds contentment without a male figure in her life. She loves the same plays and stories that she did when she herself starred in them, and yet the import of those classics have changed for her. She has drawn courage from art, literature and books. She recognizes that just because she did not have a fruitful relationship in her marriage, doesn't mean that the concept of marriage is flawed. She 


\section{DOI: https://doi.org/10.24113/ijellh.v8i1.10355}

is fortunate enough to come across men like Vasant and Satya too, for whom beauty isn't just skin deep. There are a million takeaways from this neat little novel, but most of all, this story is the journey of Anupama on her way to become Mahashweta. It is her growth as a person that we need to applaud. The novel proves the proud feeling of being a phenomenal woman as quoted by Maya Angelo:

"I'm a woman Phenomenally. Phenomenal woman, That's me." 
DOI: https://doi.org/10.24113/ijellh.v8i1.10355

\section{Works Cited}

Murthy, Sudha.MAHASHWETA.2000.NEW DELHI: Penguin Books, 2007.Print

Jackson, Elizabeth. Feminism and Contemporary Indian Women's Writing, 2010. Palgrave Macmillan. Print

"Sudha Murty." wikipedia.org. Wiki. Web. January 18, 2016.

https://www.goodreads.com/book/show/13208.Phenomenal_woman 